\title{
Mission and reception of St Justin Popović
}

\author{
Zdenko Š. Širka \\ Protestant Theological Faculty of Charles University (Prague, Czech Republic) \\ zdenko.sirka@gmail.com \\ https://orcid.org/0000-0002-1573-3800
}

Vladimir Cvetković, Bogdan Lubardić (eds.), Thought and Mission of St Justin Popović: International Thematic Conference Proceedings, Belgrade 2019, 422 p. Bogdan Lubardić, Justin of Ćelije and England: Ways of Reception of British Theology, Literature and Science, Belgrade 2019, $224 \mathrm{p}$.

Владимир Цветковић и Богдан Лубардић (ур.), Мисао и мисија Свет̄о̄ Јусиична Пойовића: међунарояни иеммайски зборник, Београд - Ниш: Институт за филозофију и друштвену теорију Универзитета у Београду Православни богословски факултет Универзитета у Београду — Центар за византијско-словенске студије Универзитета у Нишу, 2019, 422 стр.

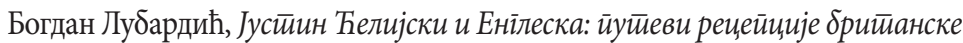
иееолоіије, книжевносии и и науке, Београд: Институт за теолошка истраживања - Православни богословски факултет Универзитета у Београду, 2019, 224 стр.

This review essay brings a closer look at two books about Serbian saint and theologian Justin Popović, both were published in 2019 in Serbian. The first one, presented and analysed in this review, is the international thematic conference proceedings Mission and thought of St Justin Popović, edited by Vladimir Cvetković and Bogdan Lubardić from the Orthodox Theolog-

"This work has been supported by Charles University Research Centre program No. 204052. 
ical Faculty in Belgrade (Serbia). The second one, presented in the next review, is Justin of Ćelije and England: Ways of Reception of British Theology, Literature and Science, written by Bogdan Lubardić. There is no need to introduce the life and work of Justin Popović (1894-1979) to the readers of this journal as it is generally known: monk and saint of the Orthodox Church (St Justin the New of Ćelije), professor at the University of Belgrade, co-founder of the Serbian Philosophical Society, one of the most prominent and important Orthodox theologians of the twentieth century. In my modest opinion, these two books open a new chapter in the research of Justin Popović's lega$c y$, in contrast to revival-apologetic and descriptive approach that previously dominated the reception of Justin Popovićs thoughts. This new approach is characterized by a non-ideological approach to Justin's work and balances between two extremes, in a certain sense it proposes a middle path. The first extreme, pietistic and defensive-panegyric, considers any criticism of Justin's work to be a direct attack on his holiness. The second extreme finds in Justin's work a justification to reject the Serbian Church and all Orthodoxy due to their anti-modern and retrograde nature. Both extremes had fed each other for years and insist on the objectivity and complete truthfulness of their own interpretation of Justin's work. The proposed middle ground no longer has as the starting point of whether Justin's views are correct or not, but it considers the reasons and circumstances in which Justin's work occurs.

The conference proceedings of justinological studies Studia Iustiniana Serbica Collationes brings extended and redacted papers presented at the conference Mission and thought of St Justin Popović organized in Belgrade on May 10 and 11, 2019 by the Institute of Philosophy and Social Theory (Belgrade), by the Orthodox Theological Faculty of the University of Belgrade and by the Center for Byzantine-Slavic Studies at the University of Niš. This conference was a scientific forum for the formulation of new scientific-methodological approaches and for a 
more thorough interpretation of Justin Popovićs legacy, especially with regard to his critique of humanism, Catholicism and Protestantism. The conference participants tried to find ways of carefully distinguishing between the authentic spirituality of Justin Popović and its reduction, instrumentalization and ideologization. They made assumptions for the undeniably important contribution of Justin Popovic's thought: thought that, according to the participants' opinion, is relevant not only for Orthodoxy, but for Christian theology and spirituality per se. Hence the published volume from a broader historical-theoretical perspective shows the status of the research of Justin's lega-

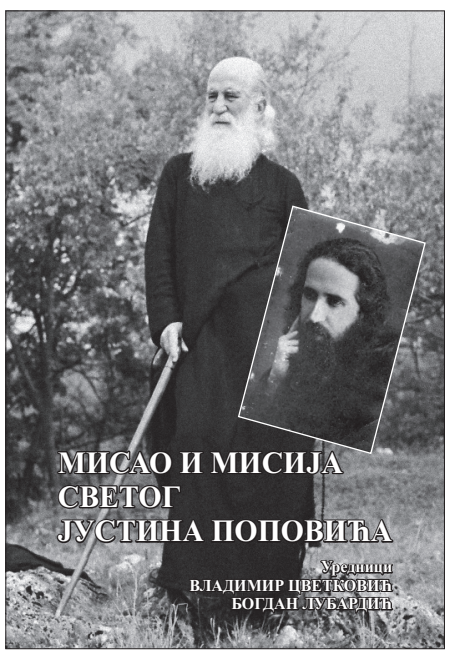
cy both in domestic and foreign academic circles. From the 33 lectures presented at the conference 24 are included in this collection, many of them are by Orthodox theologians of Serbian, Greek, Russian, Bulgarian, or Western provenance, present are even Roman Catholic or Lutheran theologians.

A few words about editors. Vladimir Cvetković (*1970) is currently working at the Institute for Philosophy and Social Theory in Belgrade. He gained his education at Durham University and worked as a research and teaching fellow at the universities of Princeton (USA), Aarhus (Denmark), St Andrews (Scotland, UK), Oslo (Norway) and Niš (Serbia). Trained in patristics, Byzantine philosophy and Orthodox theology he wrote books on Gregory of Nyssa and on the perception of the West in contemporary Serbian Orthodoxy, noteworthy are also two edited volumes on Georges Florovsky's ecumenism. One of the things he emphasizes in his justinological studies is the previously overlooked presence of Maximus the Confessor in Popovićs theological opinion, especially in connection with the doctrine of the human person as the image of God. The 
second editor is Bogdan Lubardić ("1964), the Head of the Department for philosophy and religion studies at the Orthodox Theological Faculty of the University of Belgrade. He translated many important works by foreign authors (Vladimir Lossky, John Meyendorff, Kallistos Ware, John Zizioulas) into Serbian, but attracted attention with his authorial monographs (on Lev Shestov, Nikolai Berdyaev, and Justin Popović). His two monographs on Justin Popović (Justin of Ćelije and Russia, 2009 and Justin of Ćelije and England, 2019), but also his pedagogical and organizational activity, made him the custodian of Justin's legacy.

Cvetković and Lubardić are not only editors of the conference proceedings and organizers of the conference, but together they wrote an introductory chapter "Justinological studies in a Serbian and European context" which is, in a certain sense, a manifest of the new critical interpretation of St Justin Popović. In this chapter they show that the reception of Justin Popović's work is quite a complex and, in a sense, delicate issue due to certain aspects that still cause either doubts or the most contradictory opinions. They show that reception and interpretation of Justin's work during the last four decades (1979-2020) took place under the strong influence of historical and political events in the Balkans and was mostly ideological, hence they reconstruct several phases of the reception of Popović (p. 8). It is important to explain this further.

The first phase (from 1979 to 1990) is marked by the care of Justin's written legacy by his closest students, most notably Atanasije Jevtić and Amfilohije Radović. The second phase dates back to the 1990s, when Popović was discovered by the general public, but at the same time, however, continued the purposeful interpretation of his work for ideological purposes. The recognition of Croatian independence by leading Western countries significantly affected the decline in interest in Justin's anti-communism, which was replaced by an emphasis on his critique of papal authority and Roman Catholicism; the ecclesiological claims of the papacy to universal 
jurisdiction have been interpreted as the Vatican's efforts for absolute power, which is incompatible with Christianity itself - this resulted in an increased interest in Justin's stance on ecumenism. The third phase began in the late 1990s, when Anti-Western sentiment in Serbian society culminated - fuelled by the policies of Western countries from the early 1990s, first by the break-up of Yugoslavia and then by economic and military support to parties with which Serbs were in armed conflict with during the war. Ignoring Serbia's national interests, the bombing of Serbia in 1999 was seen only as the culmination of this long-standing West policy towards Serbia. For this reason, interest in Justin's critique of the papacy has been replaced by an interest in his critique of humanism and rationalism, and his critique of Western anthropocentric and secularist values has come to the fore.

The end of the first decade of the $21^{\text {st }}$ century is when the next, fourth, phase in the academic reception of the Serbian thinker's legacy started, characterized by the rise in the academic study of the spiritual and philosophical-theological contribution of Justin Popović. This momentum, as the editors admit (p.13) is to some extent the result of the scientific project Serbian Theology in the Twentieth Century, which took place under the auspices of the Ministry of Science of the Republic of Serbia in two research cycles (2006-2010 and 2011-2015), and enabled an approach to Popović from different theoretical and methodological perspectives: from a dogmatic, liturgical, hagiological, patrological, philosophical, biblical, cultural and pedagogical educational perspective. This scientific project was a decisive impulse for the rise of an open academic debate on the interpretations of the work of Justin Popović. This impetus established the, until then missing, necessary conditions for the possibility of establishing justinology as a specialist discipline of Serbian and Orthodox patrology in general, which led to the latest, fifth, phase in the scientific-academic reception of Father Justin's legacy (p. 18). Justin's work is no longer perceived only within theological disciplines, but also within the broad- 
er framework of the humanities and social sciences. Another point is that authors from abroad and from other denominations are also involved in Justin-research, and find in Justin's work a source of new and original interpretations. In this sense, we must perceive the recent (2019) international conference entitled Mission and Thought of St Justin Popović.

Authors involved in the reviewed conference proceedings often demythologize and de-instrumentalize Justin's work, but do not prove that it is less valuable or even worthless, as Justin's domestic and foreign critics would like; on the contrary, they show that it is far more philosophically and theologically relevant than its uncritical conservative admirers would prefer (p. 20). The justinological studies included in this volume bring a perspective of various humanistic disciplines (from theology and philosophy, through the theory of literature, to psychology, pedagogy and historiography), and hence show the value of Justin's work in the broader context of socio-humanistic disciplines. The Serbian saint is not presented as an ideological construct, nor is his work used to establish one's ideological position, but his thought is presented on the basis of external intellectual-cultural, socio-political and wider ecclesiastical and inter-confessional circumstances. All this shows that justinological studies have ceased to be a scientific discourse limited to one national culture and significant only within its locality, as one third of the papers included in this collection are the original conference presentations presented in English, and originally written in Russian, French, German, Czech, Bulgarian and Greek.

The collection contains 24 works divided into six thematic units, which depict the directions in which the reception of Justin Popovićs work moves. The first thematic area "Justin Popović between ecumenism and anti-ecumenism" concerns the ecumenical and anti-ecumenical views of Father Justin; it contains chapters from both editors as well the Catholic perspective from prof. Thomas Bremer of the University in Munster, and the Lutheran perspective of a theologian from the Czech Republic. All four works show that Justin's relations with 
the Anglican, Roman Catholic and Lutheran Churches, as well as his relations with the institution of the papacy, are more nuanced and subtler than was understood previously. The next thematic unit "Justin Popović, Dostoevsky and religious philosophy" refers to Popović's reading of Dostoevsky and his heritage, which is a link that ties together philosophy, literary criticism and theology. The works within this thematic unit shed light on various aspects of Popovićs reading of Russian religious philosophy, as well as the creative adoption of some key ideas. The third thematic area "Anthropology of Justin Popović" is dedicated to the anthropology of Justin Popović, which represents a significant contribution to Christian and philosophical anthropology in general. The works on this matter point to the supporting pillars of Justin Popović's anthropology, such as the dialectic of human-centeredness and God-centeredness, or the spiritual dimensions of human nature, faith, grace and asceticism. The fourth thematic unit "Justin Popović: hagiographer, preacher, dogmatist, liturgist" deals with various aspects of the priestly ministry of Father Justin and his theological activities, which illuminates him as a clergyman, preacher, missionary, dogmatist and liturgist. This thematic section deepens the understanding of various aspects of Justin's personality and his ministry, but also his theological opus. The fifth thematic area "Justin Popović and the West" is dedicated to Justin Popovićs attitude towards the West, which has often been described in previous research as too critical. The sixth and last part "Valorisation and Reception" (p. 365) deals with the reception of Justin Popović in certain environments and within certain historical contexts. It clearly shows the ways and means in which Father Justin reached his readers around the world as well as some of the reasons for his receptivity to others.

These thematic conference writings are recommended to all interested in Justin Popović and his world, but also to those interested in dogmatics, spirituality, theological anthropology, modern Orthodox theology, ecumenism, and patristics. The thematic conference materials are written in Serbian and non- 
Serbian-speaking readers will have to wait either for an English translation or can hope that individual authors will publish their texts in English; both are highly recommended. The same can be said about the authorial monographs of Bogdan Lubardić, one of the editors.

The books of Bogdan Lubardić from the Orthodox Theological Faculty in Belgrade are famous for their careful and precise elaboration and this is also the case with his latest book Justin of Celije and England: Ways of Reception of British Theology, Literature and Science. There we can find a clearly described and then consistently followed methodology, cautious conclusions, detailed research, clear and comprehensible structure, consistent argumentation, precise expressions, objective evaluation of the analysed topics and reasoning of individual statements. Still, the author's vocabulary is not sterile, quite the contrary, reading this book can be compared to reading a detective story, where you consume word after word, just to find out what it was really like with Justin Popović in England.

The book Justin of Ćelije and England creates a diptych with the book written 10 years earlier (Justin of Ćelije and Russia, 2009) and in both books Lubardić follows aspects of Christian traditions with which Justin Popović communicated (p. 12). While in the book on Russia Lubardić dealt with the relation of Justin's work to the world of Russian Orthodox spirituality, in the reviewed book Justin of Ćelije and England the author focuses on Father Justin's ideas in relation to the world of Anglican spirituality and British culture. This step is indeed logical and expected if it is known that after his studies in St. Petersburg (1916) Justin continued his education in Oxford (1916-1919). The biographical and educational context of his life is thus immersed in a much broader and more fundamental context, which Lubardić calls the intellectual-existential context. The author is aware that behind Justin's ideas and thoughts one can find other thinkers; he does not want to say that Popović is performing some kind of synthesis, but 
this awareness is an inevitable consequence of hermeneutically consistent reflection. In the spiritual sense, Popović encountered a number of thinkers, with whom he forms a spiritual-intellectual community that is not completely reducible only to a circle of Orthodox thinkers. Being aware of this fact led the author of the book to read Popović more inclusively, both in relation to Orthodox and in relation to other forms of Christian traditions (p. 11).

One of the highlights of this book is the methodology used. Lubardićs method of interpretation was already evident in his previous publications, but now is it clearly described in detail. It consists of the use of the hermeneutics of Hans-Georg Gadamer (1900-2002), more specifically in the application of effective history (Wirkungsgeschichte), which allowed Lubardić not only to reconstruct the basic context and assumptions of Justin's starting position for building neopatristic Christian philosophy, but also to introduce a mechanism of so-called selective reception. In short, Gadamer's methodology helped Lubardić to become aware that all received texts or ideas are not reciprocated statically or objectively, but are interpreted; what's more, interpreted from a specif-

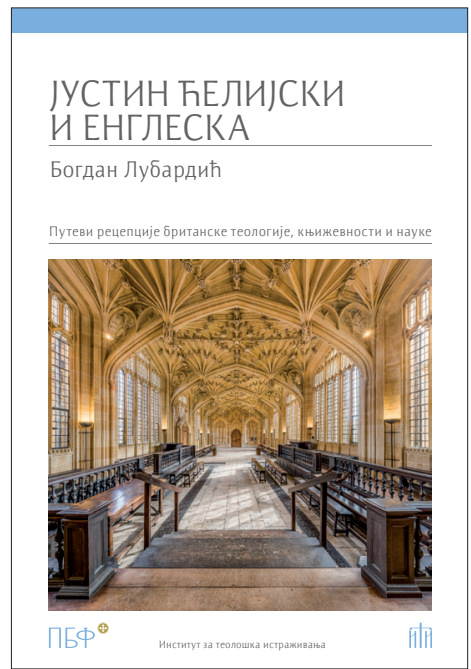
ic point of view. This means that Father Justin's thoughts and texts should be considered in the context of those texts/authors/ideas that he himself reciprocated. If we do not do so, Lubardić realizes, we remain to some extent caught in a precritical way of understanding (p. 20). In his book Lubardić shows that Justin's texts and thoughts can, to some extent, be understood as the effects of his own (i.e. Justin's) reading; but it is not important only whether and to what extent and in what way these are the ideas and texts of Dostoevsky, Floren- 
sky, Florovsky or Khomjakov (i.e. not just an inventory of influences), but one must follow the effective history wherever it leads us, both the main and seemingly secondary structures and roots that are contained and assumed in Justin's texts. In other words, without looking at the way the text is received in its history, with the socio-historical context of all stages of transmission, its interpretation may be false or misleading precisely because of, say, ideological intentions that we may not be aware of.

The application of the hermeneutic method helped Lubardić to achieve some results. First of all, it enabled him to underline that Justin Popović is an independent thinker in the neopatristic synthesis movement and, at the same time, one of the pioneers of this movement. Lubardić labels Justin's theological method as selective reception. This methodology functions as a mechanism for the synthesis of spiritual and cognitive forms, to which Popović responds. In a critical dialogue with others, Popović filters the heterodox ideas, but accepts those he considers synthetically stimulating and Orthodox. Popovic complements the method of selective reception with the criterion of reasoning, diakrisis (p. 29). As a result, Justin incorporates into his Christian philosophy and theology only what passes the critical test of thinking, and confirms the received content with his own seal - the dogma of Christ the Godman. The chosen hermeneutic approach allows Lubardić to avoid both the temptation to idealize Popovićs thinking and the temptation to arrogantly disqualify his thinking. He searches for a possibility, a middle path, that would avoid both of these extremes and which would also preserve the seriousness of Justin's thoughts and theology. Lubardić respects the fact that Popović is a saint and a great thinker, but still is aware that like everyone else, he bears the stamp of the finitude. Lubardic does not perceive the undeniable holiness of Justin Popović as an alibi for literal or superstitious ideological reading "on his behalf".

It is obvious that Bogdan Lubardić is concerned with creating preconditions and establishing justinology as an offshoot 
of Orthodox patrology, but the main task of his book is to create space for new possibilities of understanding the work of Justin Popović while at the same time preserving the integrity of his work. Henceforward Lubardić sees it as appropriate to shed light on the basic preconditions of Justin's spiritual, theological and philosophical thinking from new perspectives. $\mathrm{He}$ believes that introducing new contextual dimensions will ensure Popović the academic scientific and spiritual credibility that his work deserves.

The book contains six chapters; a description of the methodology and scientific research approach is in the first chapter. The story of Popović and England per se begins with the second chapter, entitled "Oxford: Justin Popović and Walter Frere: A Controversial Final Thesis on Dostoevsky - An Attempt to Mediate Horizons." Namely, during World War I, the Theological Faculty in Oxford welcomed a group of at least 55 theological refugees from Serbia - seminarians, professors and clergy. It was a non-trivial gesture of the British authorities that influenced the historical and social relations between two churches, and thanks to which the formation of theologians from the Serbian Orthodox Church in seminaries was preserved. Justin Popović was among the first ones to arrive in 1916, and he was accepted into a study program to obtain the title of Bachelor of Letters (Baccalaureus Litterarum, B.Litt.). His thesis was titled The Religion of Dostoevsky, but Justin did not defend it and did not obtain a certified degree from the university. In scientific circles this "Oxford debacle" (p. 40) is considered a controversial and rather vague matter, very complicated and, above all, sensitive. Examiners Walter Frere and Nevill Forbes acknowledged in their review that the work was a detailed and eloquent interpretation of Dostoevsky's religious beliefs, but criticized it for lack of any criticism and that it did not offer a reflection about Dostoevsky's relation to events in Russia and Russian Orthodoxy at that time. Opponents felt that Popović did not question Dostoevsky's assumptions at all, but accepted them as a predeter- 
mined truth, which he himself "preached" rather than subjected to a critical approach.

Lubardic examines the pros and cons of this issue and convincingly shows that in contrast (and in addition) to his negative view of Western Christianity, which is the main reason why Justin's work has not been accepted, Justin Popović in some passages also suggests a positive and inclusive relationship with Western Christianity (p. 40). This fact may somewhat revise the widespread view that Justin's thinking is anti-Western. Lubardić reveals this positive relationship in a number of positive references to Anglican thinkers, theologians and poets, as well as British naturalists. He accepts the allegation that Justin's dissertation lacks a meta-critical perspective, and acknowledges that opponents were more than competent to comment on this point. Among others, Lubardić suggests that opponents may even have fallen into the trap of fearing that Popovic's disqualification of ungodly humanism would also disqualify the entire Western Christian civilization and culture as such - as Lubardić tries to show, total disqualification of the West was never what Popović intended (p. 57). At the same time, Lubardić points out that the reviewers did not notice the pioneering dimension of Justin's thesis, as it is written according to the model of the Fathers of the Church and should be placed among the books of spiritual-ascetic literature (p. 46).

Lubardić finds out that in Justin's texts one encounters insufficiently described and researched cases of positive attitudes towards British thinkers, a detailed description of these references and connections is given in chapters 3 and 4 . In the third chapter, entitled "Justin Popović and other British Minds 1: Literature and Theology, Murry and Newman", he deals mainly with Justin's relation to John Middleton Murry and John Henry Newman. In the fourth chapter "Justin Popović and other British Minds 2: Natural Science, Eddington, Jeans, Crowther, Sullivan, Taking into Account the Theology of Logos", Lubardić underlines the influence of recent 
astrophysical and physical cosmological facts and theories of British Anglican scientists on Justin. Popović sees these theories as spiritually meaningful and integrates them into his philosophical theology. Here Lubardić brings a new and surprising discovery of how Justin uses Maxim the Confessor's theology of logos and logoi spermatikoi in order to integrate and define the results of the new physical sciences of the first third of the $20^{\text {th }}$ century (p. 134). Namely, Justin Popović believes that in each visible logos is an invisible, still distinct manifestation of the intention of the divine Logos. He uses the latest scientific discoveries of his time about the meaning of invisible structures behind the visible matter as proof that everything comes from the invisible creative Logos Christ the Almighty. In short, everything strives for invisibility and infinity, ad infinitum, because everything derives from the creative principle of the Invisible. The model of Maxim the Confessor is thus for Justin, as Lubardić sees it, a model according to which the results of modern sciences can be theologically confirmed. Equally important is also Justin's convergence with the Anglican critique of the First Vatican Council, and his admiration for some English writers and poets (Shakespeare and Thompson). In the fifth chapter "Reflections from the Library of Justin of Celije: Theological Beams in English: Butler, Illingworth, Holland, Sayce, Pass, and Thompson's Theopoetics" Lubardić visits and explores Justin's own library (still located in the Ćelije Monastery), analyses the English books he found there, and explains their meaning for Justin Popović. The sixth chapter "Conclusion: Truth in Love and Love in Truth" is the prologue of the whole book and Lubardić brings here a final reflection.

What is the message we can take from this book? Certainly, it is an awareness that for Justin Popović spiritual empathy and respect for the Western Christian style were an expression of love for the truth, even though Justin means the truth of the (Orthodox) Church. Lubardić emphasizes that Justin's position is paradoxical only seemingly, or rather, it is formal- 
ly paradoxical, but it is not fundamentally contradictory ( $\mathrm{p}$. 131). Considering more inclusive reflection of Western Christianity should be reason enough not to prematurely reject Justin's entire theological and philosophical work. On the contrary, one can pay particular attention to Justin Popovićs life as a pilgrim, confirmed in prayer and asceticism, in the liturgical ministry and in spiritual contemplations about the mysteries of life with Christ in God. Justin's life and work were a deeply engaged witness in a time of spiritual crisis, and the source of his ideas is exactly this liturgical-ascetic communion with the living God-Man, it is not an anti-Western intellectual agen$\mathrm{da}$, and therefore Orthodoxy should not be reduced to a religious-geopolitical matter. It must be emphasized once again, together with Lubardić, that for Justin, the "West" is a rhetorical-polemical topos that encompasses the whole of Europe, including the "Eastern" (p. 132).

Thus, if we saw the first major benefit of the peer-reviewed book to be in offering a new methodology that allows a much more comprehensive and holistic interpretation of Justin's thoughts, the second major benefit is a pioneering presentation of both the historical circumstances of Justin Popovic's stay in England and their hermeneutic reflection, which showed (somewhat surprisingly) Justin's fundamental closeness to Western Christianity and British culture.

Both publications together open a new chapter in Justinresearch and so contribute to the justinological debate. Let us hope that other books and publications will follow. 